\title{
PENGARUH STORE ATMOSPHERE TERHADAP KEPUASAAN KONSUMEN PADA CAFE REFRESHO DI KOTA PALU
}

\author{
FIRDHA NUR ATIFA \\ WAHYUNINGSIH \\ PONIRIN \\ Jurusan Manajemen, Fakultas Ekonomi, Universitas Tadulako \\ Email: firaatifa@gmail.com
}

\begin{abstract}
This research aims to determine the influence of store atmosphere on consumer satisfaction at Cafe Refresho in Palu City. The independent variables used in this study are Exterior (X1), General Interior (X2), Store Layout (X3) and Interior Display (X4), while the dependent variable is consumer satisfaction $(Y)$. This type of research is quantitative. The method of this research is descriptive causal. Samples used in this study are 100 respondents and using purposive sampling technique. Data analysis method used in this research is multiple linear regression analysis method. The results of this study indicate that simultaneously Store Atmosphere elements consisting of Exterior, General Interior, Store Layout, and Interior Display have a significant effect on consumer satisfaction at Cafe Refresho in Palu City. Partially Store Atmosphere elements consisting of General Interior, Store Layout, and Interior Display have a significant effect on consumer satisfaction at Cafe Refresho in Palu City. While the Exterior element partially have no significant effect on consumer satisfaction at Cafe Refresho in Palu City.
\end{abstract}

Keywords: Elements Store Atmosphere and Consumer Satisfaction.

\begin{abstract}
ABSTRAK
Penelitian ini bertujuan untuk mengetahui pengaruh store atmosphere terhadap kepuasan konsumen pada Cafe Refresho di Kota Palu. Variabel independen yang digunakan dalam penelitian ini adalah Exterior (X1), General Interior (X2), Store Layout (X3) dan Interior Display (X4), Sedangkan variabel dependen adalah kepuasan konsumen (Y). Jenis penelitian ini adalah kuantitatif. Metode penelitian ini adalah deskriptif kausal. Sampel yang digunakan pada penelitian ini yaitu sebanyak 100 responden dengan bentuk pengambilan sampel menggunakan teknik purposive sampling. Metode analisis data yang digunakan dalam penelitian ini adalah metode analisis regresi linear berganda. Hasil penelitian ini menunjukkan bahwa secara serempak elemen Store Atmosphere yang terdiri dari Exterior, General Interior, Store Layout, dan Interior Display berpengaruh signifikan terhadap kepuasan konsumen pada Cafe Refresho di Kota Palu. Secara parsial elemen Store Atmosphere yang terdiri dari General Interior, Store Layout, dan Interior Display berpengaruh signifikan terhadap kepuasan konsumen pada Cafe Refresho di Kota Palu. Sedangkan elemen Exterior secara parsial berpengaruh tidak signifikan terhadap kepuasan konsumen pada Cafe Refresho di Kota Palu.
\end{abstract}

Kata kunci: Elemen Store Atmosphere dan Kepuasan Konsumen.

\section{PENDAHULUAN}

Gaya hidup masyarakat masa kini lebih cenderung menyukai makanan jadi untuk mempersingkat waktu dan praktis. Hal ini menunjukan bahwa pemenuhan kebutuhan pangan manusia akan berdampak pada semakin besarnya peluang pengembangan bisnis industri food service di Indonesia. Itulah lah yang menyebabkan maraknya pengusaha membuka dan menginvestasikan usaha di bidang jasa penyedia makanan dan minuman atau biasa disebut cafe and resto termasuk di Kota Palu.

Salah satu cafe yang hadir dari sekian banyak cafe di Kota Palu yaitu Cafe Refresho. Konsep yang digunakan dalam cafe ini adalah konsep art \& vintage. Cafe ini juga berada di lokasi yang mudah dijangkau sehingga cafe ini dapat dikatakan memiliki peminat yang cukup banyak. Namun dalam beberapa bulan terakhir pengunjung mengalami fluktuasi jumlah konsumen, oleh karena itu, upaya 
untuk meningkatkan jumlah konsumen dan kepuasan konsumen Cafe Refresho perlu dilakukan dalam persaingan bisnis.

Salah satu cara untuk memenangkan persaingan adalah dengan membuat sesuatu yang berbeda. Store atmosphere bisa menjadi alternatif untuk membedakan cafe yang satu dengan yang lainnya. Perbedaan diperlukan karena dari setiap bisnis pasti didapati produk yang serupa dengan harga yang berkisar beda tipis. Store atmosphere bisa menjadi alasan lebih bagi konsumen untuk tertarik dan memilih dimana ia akan berkunjung dan membeli (Aji, 2016)

Berdasarkan fenomena turunnya jumlah pengunjung di Cafe Refresho maka perlu adanya penelitian yang bertujuan untuk mengetahui mengapa jumlah pengunjung tersebut menurun dengan meneliti pengaruh store atmosphere yang terdiri dari Exterior, General Interior, Store Layout, dan Interior Display terhadap kepuasan konsumen membeli pada Cafe Refresho di Kota Palu. Adapun tujuan yang ingin dicapai dalam penelitian ini adalah:

1. Untuk mengetahui dan menganalisis pengaruh store atmosphere yang terdiri dari Exterior, General Interior, Store Layout, dan Interior Display secara simultan terhadap kepuasan konsumen membeli pada Cafe Refresho di Kota Palu.

2. Untuk mengetahui dan menganalisis pengaruh Exterior secara parsial terhadap kepuasan konsumen membeli pada Cafe Refresho di Kota Palu.

3. Untuk mengetahui dan menganalisis pengaruh General Interior secara parsial terhadap kepuasan konsumen membeli pada Cafe Refresho di Kota Palu.

4. Untuk mengetahui dan menganalisis pengaruh Store Layout secara parsial terhadap kepuasan konsumen membeli pada Cafe Refresho di Kota Palu.

5. Untuk mengetahui dan menganalisis pengaruh Interior Display secara parsial terhadap kepuasan konsumen membeli pada Cafe Refresho di Kota Palu.

\section{KAJIAN LITERATURE}

\section{Pengertian Store Atmosphere}

Suasana toko (store atmosphere) adalah desain lingkungan melalui komunikasi visual, pencahayaan, warna, musik, dan wangi-wangian untuk merancang respon emosional dan persepsi pelanggan dan untuk memengaruhi pelanggan dalam membeli barang (Utami, 2010).

\section{Elemen-Elemen Store Atmosphere}

Elemen-elemen dari store atmosphere menurut Berman dan Evan (2010:509) terdiri dari bagian luar (exterior), bagian dalam (general interior), tata letak toko (store layout) dan dekorasi atau pajangan (interior displays). Yang akan dijelaskan sebagai berikut:

a. Bagian Luar (Exterior). Bagian luar restoran adalah bagian yang termuka. Maka bagian ini hendaknya memberikan kesan yang menarik. Dengan mencerminkan kemantapan dan kekokohan, maka bagian depan dan bagian luar ini dapat menciptakan kepercayaan. Disamping itu, hendaklah menunjukan spirit perusahaan dan sifat kegiatan yang ada di dalamnya.

b. Bagian Dalam (General Interior). General interior adalah bagian dalam toko. General Interior meliputi merencenakan, menata dan merancang ruang-ruang dalam bangunan.

c. Tata Letak Toko (Store Layout). Store layout adalah tata letak toko. Perencanaan store layout meliputi penataan penempatan ruang untuk mengisi luas lantai yang tersedia, menentukan lokasi tertentu dan pengaturan dari jalan atau gang di dalam toko yang cukup lebar dan memudahkan orang untuk berlalu lalang, serta penempatan fasilitas toko seperti tata letak kursi/meja (Wanti, 2015).

d. Dekorasi atau Pajangan (Interior Displays). Dekorasi, pajangan, atau tanda yang menentukan bagi suasana cafe karena memberikan informasi kepada konsumen. Tujuan utamanya adalah untuk meningkatkan penjualan dan laba bagi restoran. Yang termasuk interior display ialah: poster, tanda 
petunjuk lokasi, display barang-barang atau dekorasi pada hari-hari khusus seperti lebaran dan tahun baru (Wanti, 2015).

\section{Kepuasan Konsumen}

Kepuasan konsumen merupakan hal penting bagi suatu perusahaan. Sering terlihat slogan-slogan "Pelanggan adalah raja". Menurut Kotler dan Keller (2013:150) "kepuasan merupakan perasaan senang atau kecewa seseorang yang timbul karena membandingkan kinerja yang dipersepsikan produk (atau asli) terhadap ekspektasi mereka". Sedangkan menurut Hasan (2009:57) "Penggunaan barang atau jasa yang telah dikonsumsi, akan menimbulkan perasaan senang, puas, atau kecewa. Hal tersebut akan menjadi hasil yang menentukan kepuasan atau ketidakpuasan dari suatu produk".

\section{Kerangka Pemikiran}

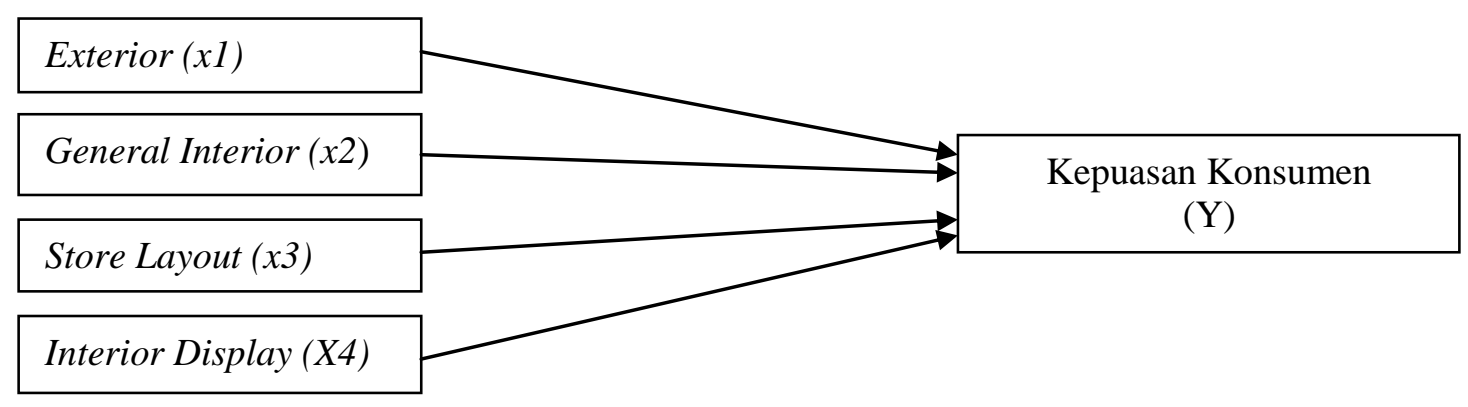

\section{Gambar.1 Kerangka Pemikiran}

\section{Hipotesis}

Dugaan sementara dalam penelitian ini yang diajukan oleh peneliti adalah:

a. Variabel-variabel store atmosphere yang terdiri dari exterior, general interior, store layout dan interior display secara simultan berpengaruh signifikan terhadap kepuasan konsumen membeli pada Cafe Refresho di Kota Palu.

b. Exterior secara parsial berpengaruh signifikan terhadap kepuasan konsumen membeli pada Cafe Refresho di Kota Palu.

c. General interior secara parsial berpengaruh signifikan terhadap kepuasan konsumen membeli pada Cafe Refresho di Kota Palu.

d. Store layout secara parsial berpengaruh signifikan terhadap kepuasan konsumen membeli pada Cafe Refresho di Kota Palu.

e. Interior display secara parsial berpengaruh signifikan terhadap kepuasan konsumen membeli pada Cafe Refresho di Kota Palu.

\section{METODE PENELITIAN}

Jenis penilitian ini adalah penelitian deskriptif dan kausal, menurut Sugiyono (2009:21) penelitian deskriptif adalah penelitian yang menggambarkan, menjelaskan variabel-variabel penelitian atau menganalisis suatu hasil penelitian”. Menurut Ferdinand (2014:7) penelitian kausal yaitu mencari penjelasan dan menganalisis hubungan sebab-akibat (cause-effect) antar beberapa variabel. Adapun menurut Sugiono (2009:13) objek penelitian (variabel penelitian) adalah segala sesuatu yang berbentuk apa saja yang ditetapkan oleh peneliti untuk dipelajari sehingga informasi tentang hal tersebut, kemudian ditarik kesimpulannya. Berdasarkan pemahaman tersebut, dalam konteks penelitian ini yang dimaksud objek penelitian adalah "Pengaruh Store Atmosphere terhadap Kepuasan Konsumen". Subjek penelitian ini adalah pengunjung Cafe Refresho. Penelitian ini dilakukan di Cafe Refresho yang berlokasi di Jalan Raden Saleh No 13. Peneliti membutuhkan waktu selama 1 bulan untuk melakukan penelitian. 
Berikut pendapat Ferdinand (2014:171) populasi adalah gabungan dari seluruh elemen yang berbentuk peristiwa, atau orang yang memiliki karakteristik yang serupa yang menjadi pusat perhatian seorang peneliti. Populasi pada penelitian ini adalah semua masyarakat yang pernah bertransaksi di Cafe Refresho minimal sekali dalam 4 bulan terakhir dan berdomisili di Kota Palu. Metode pengambilan sampel yang digunakan dalam penelitian ini adalah non-probability sampling dan menggunakan teknik purposive sampling yaitu teknik yang digunakan dalam pengambilan sampel berdasarkan dengan kriteria yang telah ditentukan.

Jumlah sampel yang akan diambil untuk mewakili populasi dalam penelitian ini sebanyak 100 sampel. Penentuan sampel sebanyak 100 responden, ini didasarkan pada teori Gay dan Diehl (1992) yaitu ukuran sampel yang dapat diterima berdasarkan desain penelitian kausal minimal sebanyak 30 sampel. Pertimbangan memilih 100 responden, karena keterbatasan kemampuan peneliti untuk mengambil sampel yang lebih besar di mana semakin besar sampel yang digunakan semakin besar pula biaya, waktu, tenaga yang dikeluarkan. Adapun sampel dalam penelitian ini:

1 Berusia minimal 17 tahun, hal ini didasarkan pada umur kedewasaan sehingga diharapkan dapat memberikan jawaban yang dapat dipeertanggung jawabkan dan mengerti dengan isi pertanyaan.

2. Pernah mengunjungi Cafe Refresho minimal sekali dalam kurun waktu 4 bulan terakhir di tahun 2017.

3. Berdomisili di Kota Palu.

Selanjunya analisis data yang digunakan pada penelitian ini adalah analisis kualitatif menggunakan regresi linier berganda. Analisis kualitatif merupakan analisis data yang dilakukan dengan cara mengumpulkan, membandingkan, menganalisis data berupa tabel-tabel dan grafik, profil responden yang dianalisis dengan cara mentabulasikan data yang diperoleh dengan prosentase serta menjelaskan mengenai Store Atmosphere yang mempengaruhi kepuasan pelanggan.

Analisis Regresi Linier Berganda menggunakan bantuan komputer program SPSS Release 22.0. Bentuk formulasi alat analisis statistik Regresi Linear Berganda secara matematis dapat dijabarkan sebagai berikut (Yamin \& Kurniawan, 2014, p. 82):

$$
Y=b_{0} b+b_{1} X_{1}+b_{2} X_{2}+\ldots \ldots+b_{n} X_{n}+e
$$

Dimana:

$\mathrm{Y} \quad=$ Variabel dependen

$\mathrm{b}_{0} \quad=$ koefisien regresi/ konstanta

$\mathrm{b}_{1-\mathrm{b}_{\mathrm{n}}}=$ koefisien regresi

$\mathrm{X}_{1}-\mathrm{X}_{\mathrm{n}}=$ variabel independen

$\mathrm{e} \quad=$ error/residu

Bila informasi matematis Regresi Linear Berganda tersebut diaplikasikan dalam penelitian ini, maka akan diperoleh bentuk persamaan sebagai berikut:

$$
Y=a+b_{1} X_{1}+b_{2} X_{2}+b_{3} X_{3}+b_{4} X_{4}+e
$$

Keterangan:

$\begin{array}{lll}\mathrm{A} & = & \text { Konstanta } \\ \mathrm{Y} & = & \text { Kepuasan Konsumen } \\ \mathrm{b} 1, \mathrm{~b} 2, \mathrm{~b} 3, \mathrm{~b} 4 & = & \text { Koefisien Regresi masing-masing Variabel } \\ \mathrm{X}_{1} & = & \text { Exterior } \\ \mathrm{X}_{2} & = & \text { General Interior } \\ \mathrm{X}_{3} & = & \text { Store Layout } \\ \mathrm{X}_{4} & = & \text { Interior Display } \\ \mathrm{E} & = & \text { Error } / \text { residu }\end{array}$




\section{HASIL DAN PEMBAHASAN}

\section{Hasil Uji Validitas dan Reliabilitas}

Berikut ini adalah hasil uji validitas dan reliabilitas atas item pertanyaan yang terdapat dalam kuesioner penelitian terhadap variabel Exterior(X1), General Interior(X2), Store Layout(X3), Interior Display (X4) dan Kepuasan Konsumen (Y). Adapun hasilnya disajikan dalam Tabel 1 berikut:

Tabel. 1 Hasil Uji Validitas dan Reabilitas

\begin{tabular}{|c|c|c|c|c|c|}
\hline Variabel & Item & Total Correlation & Ket & Cronbach Alpha & Ket \\
\hline $\begin{array}{l}\text { Exterior } \\
\text { (X1) }\end{array}$ & $\begin{array}{l}\mathrm{X} 1.1 \\
\mathrm{X} 1.2 \\
\mathrm{X} 1.3 \\
\mathrm{X} 1.4 \\
\mathrm{X} 1.5 \\
\mathrm{X} 1.6\end{array}$ & $\begin{array}{l}0,666 \\
0,468 \\
0,528 \\
0,426 \\
0,317 \\
0.368\end{array}$ & $\begin{array}{l}\text { Valid } \\
\text { Valid } \\
\text { Valid } \\
\text { Valid } \\
\text { Valid } \\
\text { Valid }\end{array}$ & 0,726 & Reliabel \\
\hline $\begin{array}{l}\text { General Interior } \\
\text { (X2) }\end{array}$ & $\begin{array}{l}\text { X2.1 } \\
\text { X2.2 } \\
\text { X2.3 } \\
\text { X2.4 } \\
\text { X2.5 } \\
\text { X2.6 } \\
\text { X2.7 } \\
\text { X2.8 } \\
\text { X2.9 } \\
\text { X2.10 }\end{array}$ & $\begin{array}{l}0,529 \\
0,690 \\
0,577 \\
0,379 \\
0,607 \\
0,806 \\
0,623 \\
0,642 \\
0,527 \\
0,706\end{array}$ & $\begin{array}{l}\text { Valid } \\
\text { Valid } \\
\text { Valid } \\
\text { Valid } \\
\text { Valid } \\
\text { Valid } \\
\text { Valid } \\
\text { Valid } \\
\text { Valid } \\
\text { Valid }\end{array}$ & 0,876 & Reliabel \\
\hline $\begin{array}{l}\text { Store Layout } \\
\text { (X3) }\end{array}$ & $\begin{array}{l}\text { X3.1 } \\
\text { X3.2 } \\
\text { X3.3 } \\
\text { X3.4 } \\
\text { X3.5 } \\
\end{array}$ & $\begin{array}{l}0,443 \\
0,605 \\
0,327 \\
0,511 \\
0,487 \\
\end{array}$ & $\begin{array}{l}\text { Valid } \\
\text { Valid } \\
\text { Valid } \\
\text { Valid } \\
\text { Valid }\end{array}$ & 0,695 & Reliabel \\
\hline $\begin{array}{l}\text { Store Layout } \\
\text { (X4) }\end{array}$ & $\begin{array}{l}\mathrm{X} 4.1 \\
\mathrm{X} 4.2 \\
\mathrm{X} 4.3 \\
\mathrm{X} 4.4 \\
\mathrm{X} 4.5\end{array}$ & $\begin{array}{l}0,716 \\
0,827 \\
0,548 \\
0,620 \\
0,662 \\
\end{array}$ & $\begin{array}{l}\text { Valid } \\
\text { Valid } \\
\text { Valid } \\
\text { Valid } \\
\text { Valid }\end{array}$ & 0,852 & Reliabel \\
\hline $\begin{array}{c}\text { Kepuasan Konsumen } \\
\text { (Y) }\end{array}$ & $\begin{array}{l}\text { Y1.1 } \\
\text { Y1.2 } \\
\text { Y1.3 } \\
\text { Y1.4 } \\
\end{array}$ & $\begin{array}{c}0,867 \\
0,835 \\
0,946 \\
0.862 \\
\end{array}$ & $\begin{array}{l}\text { Valid } \\
\text { Valid } \\
\text { Valid } \\
\text { Valid }\end{array}$ & 0,941 & Reliabel \\
\hline
\end{tabular}

Sumber: Data diolah

Berdasarkan hasil uji validitas dan reliabilitas diperoleh bahwa seluruh variabel memiliki koefisien Cronbach Alpha (a) lebih besar dari 0,60 sehingga berdasarkan syarat minimum reliabilitas lebih besar dari 0,60 maka seluruh variabel yang digunakan reliabel dan dapat digunakan dalam penelitian. Sedangkan uji validitas terhadap seluruh variabel juga menunjukan nilai koefisien korelasi yang lebih besar dari 0,30 sehingga item pernyataan yang ada valid untuk digunakan.

\section{Hasil Uji Analisis Regresi Linear Berganda}

Penelitian ini menggunakan analisis regresi linear berganda dengan tujuan untuk menguji pengaruh Store Atmosphere terhadap kepuasan konsumen. Untuk lebih jelasnya hasil analisis regresi linear berganda dapat dilihat pada Tabel 2 berikut: 
Tabel 2 Hasil Uji Analisis Regresi Linear Berganda

\begin{tabular}{|c|c|c|c|c|c|c|}
\hline \multicolumn{7}{|c|}{ Dependen Variabel Y = Keputusan Pembelian } \\
\hline \multirow{2}{*}{\multicolumn{2}{|c|}{ Variabel Independen }} & \multicolumn{2}{|c|}{ Unstandardized Coefficients } & \multirow{2}{*}{$\begin{array}{c}\text { Standardized Coefficients } \\
\text { Beta }\end{array}$} & \multirow{2}{*}{$\mathrm{t}$} & \multirow{2}{*}{ Sig. } \\
\hline & & $\mathrm{B}$ & Std. Error & & & \\
\hline \multirow{5}{*}{1} & (Constant) & -1.436 & .371 & & -3.868 & .000 \\
\hline & $\mathrm{X} 1$ (Exterior) & .054 & .098 & .038 & .551 & .583 \\
\hline & X2 (General Interior) & .448 & .118 & .300 & 3.795 & .000 \\
\hline & X3 (Store Layout) & .475 & .107 & .329 & 4.431 & .000 \\
\hline & X4 (Interior Display) & .405 & .096 & .327 & 4.211 & .000 \\
\hline & $\begin{array}{l}\text { ple R } \\
\text { ted R Square }\end{array}$ & $4 \alpha$ & $\begin{array}{l}=0.000 \\
=0,05 \text { tingk }\end{array}$ & t kepercayaan $95 \%$ & & \\
\hline
\end{tabular}

Berdasarkan Tabel 2 di atas, dapat di tulis dalam bentuk persamaan regresi linear berganda berikut:

$$
Y=-1.436+0.054 X_{1}+0.448 X_{2}+0.475 X_{3}+0.405 X_{4}+e
$$

Penjabaran di atas menunjukkan bahwa, variabel independen yang dianalisis yaitu variabel $\left(\mathrm{X}_{1}, \mathrm{X}_{2}\right.$, $\mathrm{X}_{3}$ dan $\mathrm{X}_{4}$ ) memberikan pengaruh posotif terhadap variabel dependen (Y), yaitu kepuasan konsumen Cafe Refresho di Kota Palu. Untuk lebih jelasnya penjelasan bentuk persamaan tersebut dapat dilihat berikut ini:

1. Nilai Konstanta sebesar -1.436, artinya jika variabel (exterior, general interior, store layout, interior display) bernilai 0, maka variabel dependen (kepuasan konsumen di Cafe Refresho di Kota Palu) nilainya sebesar -1.436 .

2. Koefisien regresi dimensi Exterior $\left(\mathrm{X}_{1}\right)$ sebesar 0.054 , artinya jika Exterior naik satu satuan, maka kepuasan konsumen pada Cafe Refresho di Kota Palu naik sebesar 0.054.

3. Koefisien regresi dimensi General Interior $\left(\mathrm{X}_{2}\right)$ 0.448, artinya jika General Interior naik satu satuan, maka kepuasan konsumen pada Cafe Refresho di Kota Palu naik sebesar 0.448.

4. Koefisien regresi dimensi Store Layout $\left(\mathrm{X}_{3}\right)$ 0.475, artinya jika Store Layout naik satu satuan, maka kepuasan konsumen pada Cafe Refresho di Kota Palu naik sebesar 0.475.

5. Koefisien regresi dimensi Interior Display $\left(\mathrm{X}_{4}\right)$ 0.405, artinya jika Interior Display naik satu satuan, maka kepuasan konsumen pada Cafe Refresho di Kota Palu naik sebesar 0.405.

\section{Hasil Uji Hipotesis}

\section{Hasil Pengujian Hipotesis Secara Simultan (Uji F)}

Berdasarkan hipotesis pertama $\left(\mathrm{H}_{1}\right)$ adalah untuk mengetahui apakah Store Atmosphere yang terdiri dari eksterior, general interior, store layout, dan interior display secara serempak berpengaruh signifikan terhadap kepuasan konsumen pada Cafe Refresho di Kota Palu. Untuk lebih jelasnya hasil dapat dilihat pada Tabel 3 berikut:

Tabel. 3 Hasil Uji F (Simultan)

\begin{tabular}{|ll|l|l|l|l|l|}
\hline Model & & Sum of Squares & Df & Mean Square & F & Sig. \\
\hline 1 & Regression & 26.240 & 4 & 6.560 & 54.464 & $.000^{\mathrm{a}}$ \\
& Residual & 11.442 & 95 & .120 & & \\
& Total & 37.682 & 99 & & & \\
& & & & & & \\
\hline
\end{tabular}

Berdasarkan Tabel 3 di atas diperoleh Sig.F yaitu 0.000, artinya nilai tersebut lebih kecil dibandingkan dengan nilai yang disyaratkan yaitu $\alpha=0.05$ dengan tingkat kepercayaan $95 \%$. dengan demikian dapat dinyatakan bahwa secara simultan variabel Store Atmosphere yang terdiri dari Exterior, General Interior, Store Layout, Interior Display secara simultan berpengaruh signifikan terhadap kepuasan konsumen Cafe Refresho di Kota Palu. Maka hipotesis ini diterima. 


\section{Hasil Pengujian Hipotesis Secara parsial (Uji t)}

Hasil Uji t adalah untuk mengetahui apakah variabel $\left(\mathrm{X}_{1}-\mathrm{X}_{4}\right)$ secara parsial berpengaruh terhadap Y. Untuk lebih jelasnya hasil dapat dilihat pada Tabel 2 di atas. Berdasarkan Tabel 2 di atas hasil uji t pengujian variabel $\left(\mathrm{X}_{1}-\mathrm{X}_{4}\right)$ terhadap $\mathrm{Y}$ dijelaskan sebagai berikut:

1. Hasil Pengujian Hipotesis $\mathrm{X}_{1}$ terhadap $\mathrm{Y}$. Hipotesis kedua $\left(\mathrm{H}_{2}\right)$ adalah untuk mengetahui apakah Exterior $\left(\mathrm{X}_{1}\right)$ secara parsial berpengaruh signifikan terhadap kepuasan konsumen pada Cafe Refresho di Kota Palu. Berdasarkan tabel di atas menunjukkan bahwa exterior $\left(\mathrm{X}_{1}\right)$ memiliki nilai signifikan sebesar 0.583 . Artinya nilai tersebut $>$ dari taraf yang disyaratkan yaitu $\alpha=0.05$, maka dapat disimpulkan bahwa secara parsial eksterior berpengaruh tidak signifikan terhadap kepuasan konsumen.

2. Hasil Pengujian Hipotesis Hasil $\mathrm{X}_{2}$ terhadap Y. Hipotesis ketiga $\left(\mathrm{H}_{3}\right)$ adalah untuk mengetahui apakah General Interior $\left(\mathrm{X}_{2}\right)$ secara parsial berpengaruh signifikan terhadap kepuasan konsumen pada Cafe Refresho di Kota Palu. Berdasarkan Tabel di atas menunjukkan bahwa General Interior $\left(\mathrm{X}_{2}\right)$ memiliki nilai signifikan sebesar 0.000 . Artinya nilai tersebut $<$ dari taraf yang disyaratkan yaitu $\alpha=0.05$, maka dapat disimpulkan bahwa secara parsial General Interior berpengaruh signifikan terhadap kepuasan konsumen.

3. Hasil Pengujian Hipotesis Hasil $\mathrm{X}_{3}$ terhadap Y. Hipotesis keempat $\left(\mathrm{H}_{4}\right)$ adalah untuk mengetahui apakah Store Layout $\left(\mathrm{X}_{3}\right)$ secara parsial berpengaruh signifikan terhadap kepuasan di Kota Palu. Berdasarkan tabel di atas menunjukkan bahwa Store Layout $\left(\mathrm{X}_{3}\right)$ memiliki nilai signifikan sebesar 0.000 . Artinya nilai tersebut $<$ dari taraf yang disyaratkan yaitu $\alpha=0.05$, maka dapat disimpulkan bahwa secara parsial Store Layout berpengaruh signifikan terhadap kepuasan konsumen.

4. Hasil Pengujian Hipotesis Hasil $\mathrm{X}_{4}$ terhadap $\mathrm{Y}$

Hipotesis kelima $\left(\mathrm{H}_{5}\right)$ adalah untuk mengetahui apakah Interior Display $\left(\mathrm{X}_{4}\right)$ secara parsial berpengaruh signifikan terhadap kepuasan konsumen pada Cafe Refresho di Kota Palu. Berdasarkan tabel di atas menunjukkan bahwa Interior Display $\left(\mathrm{X}_{4}\right)$ memiliki nilai signifikan sebesar 0.000 . Artinya nilai tersebut < dari taraf yang disyaratkan yaitu $\alpha=0.05$, maka dapat disimpulkan bahwa secara parsial Interior Display berpengaruh signifikan terhadap kepuasan konsumen.

\section{Pembahasan atau Hasil Analisis Secara Simultan}

Berdasarkan hasil pengujian serta analisis yang telah dilakukan pada penelitian ini membuktikan bahwa Store Atmosphere yang terdiri dari Exterior, General Interior, Store Layout, dan Interior Display secara simultan berpengaruh signifikan terhadap kepuasan konsumen pada Cafe Refresho di Kota Palu. Berdasarkan tabel rekapitulasi regresi linear berganda dapat dilihat pengaruh hasil uji determinasi Adjusted $R$ Square sebesar 0.684. Nilai tersebut dapat diartikan bahwa seluruh dimensi bebas yakni Exterior, General Interior, Store Layout, serta Interior Display mempunyai konstribusi secara bersama-sama sebesar $68.4 \%$ terhadap variabel terikat yaitu terhadap kepuausan konsumen pada Cafe Refresho di Kota Palu. Sedangkan sisanya $(100 \%-68.4 \%=31.6 \%)$, dipengaruhi oleh variabel lain yang tidak diteliti misalnya variabel kualitas layanan, dan lain-lain.

Hasil penelitian ini sejalan dengan penelitian sebelumnya yang dilakukan oleh Albagdadi (2017) yang menyatakan bahwa elemen suasana toko yang terdiri dari exterior, general interior, store layout, dan interior display secara simultan berpengaruh signifikan terhadap kepuasan pembelian konsumen berbelanja pada Swalayan Inti Makmur di Kota Palu.

\section{Pembahasan atau Hasil Analisis Secara Parsial Exterior $\left(\mathbf{X}_{1}\right)$}

Exterior merupakan perencanaan dari bagian luar toko yang didesain sedemikian rupa sehingga terlihat unik, menarik, dan menonjol sehingga mengundang orang untuk masuk kedalam toko. Adapun indikator-indikator yang digunakan untuk mengukur elemen Exterior adalah bagian depan cafe, papan 
nama, pintu masuk, keaadaan lingkungan sekitar, lahan parkir yang luas dan keaamanan kendaraan saat parkir. Penelitian yang dilakukan pada Cafe Refresho di Kota Palu, pada elemen exterior dimana papan nama cafe merupakan indikator yang dominan dipilih oleh responden. Selain itu pintu masuk juga merupakan indikator yang dapat meningkatkan kepuasan konsumen pada Cafe Refresho di Kota Palu.

Berdasarkan hasil penelitian ini, indikator-indikator yang digunakan untuk mengukur exterior berpengaruh tidak signifikan terhadap kepuasan konsumen Cafe Refresho di Kota Palu. Hal ini menunjukan bahwa exterior Cafe Refresho bukan merupakan faktor penting yang menunjang kepuasan konsumen. Konsumen di Kota Palu tidak menunjukkan respon yang sangat aktif terhadap exterior sehingga kepuasan konsumen Cafe Refresho tidak terpenuhi melalui exterior cafe.

Hasil penelitian ini mendukung penelitian sebelumnya yang dilakukan oleh Meldarianda dan Lisan (2010) yang menyatakan bahwa sebagian besar konsumen yang datang ke Resort Cafe tidak teralu memerhatikan elemen-elemen outstore atmosphere yang meliputi tata letak papan nama, parkiran, dan lokasi. Penelitian ini juga sejalan dengan penelitian sebelumnya yang dilakukan oleh Sukma, Fuzi DH, dan Yaningwati (2012) bahwa bagian luar toko (exterior) secara parsial berpengaruh tidak signifikan terhadap kepuasan konsumen membeli di Hypermart Malang Town Square Kota Malang.

\section{General Interior $\left(\mathbf{X}_{2}\right)$}

General interior merupakan bagian dalam toko yang hendaknya memberikan kesan yang menyenangkan bagi konsumen ketika masuk di dalam toko. Adapun indikator-indikator yang digunakan untuk mengukur elemen general interior adalah lantai, pencahayaan, aroma, musik, tekstur tembok, suhu udara, karyawan rapi, karyawan ramah, teknologi, dan kebersihan dalam cafe. Dari penelitian yang dilakukan pada Cafe Refresho di Kota Palu, pada elemen general interior dimana musik merupakan indikator yang dominan dipilih oleh responden. Selain itu kebersihan dan karyawan yang ramah juga merupakan indikator yang dapat meningkatkan kepuasan konsumen pada Cafe Refresho di Kota Palu.

Berdasarkan hasil penelitian ini, indikator-indikator yang digunakan untuk mengukur general interior berpengaruh signifikan terhadap kepuasan konsumen Cafe Refresho. Hal ini menunjukkan bahwa general interior dapat mempengaruhi kepuasan konsumen pada Cafe Refresho di Kota Palu. Hasil penelitian ini sejalan dengan penelitian sebelumnya yang dilakukan oleh Tendean \& Widodo (2015) yang menyatakan bahwa general interior secara parsial berpengaruh signifikan terhadap kepuasan konsumen pada Maja House Sugar and Cream Bandung.

\section{Store Layout $\left(\mathbf{X}_{3}\right)$}

Store Layout merupakan rencana untuk menentukan lokasi tertentu atau penempatan fasilitas didalam toko dan pengaturan jalan/gang di dalam toko. Adapun indikator-indikator yang digunakan untuk mengukur elemen Store Layout adalah jalan dalam cafe, penempatan fasilitas cafe, penempatan kursi dan meja, penempatan kasir, dan penempatan panggung dalam cafe. Penelitian yang dilakukan pada elemen Store Layout dimana penempatan fasilitas toko merupakan indikator yang dominan dipilih oleh responden. Selain itu penempatan kasir dan panggung juga merupakan indikator yang dapat meningkatkan kepuasan konsumen pada Cafe Refresho di Kota Palu.

Berdasarkan hasil penelitian ini, indikator-indikator yang digunakan untuk mengukur Store Layout berpengaruh signifikan terhadap kepuasan konsumen Cafe Refresho. Hal ini menunjukkan bahwa Store Layout dapat mempengaruhi kepuasan konsumen pada Cafe Refresho di Kota Palu. Hasil penelitian ini sejalan dengan penelitian sebelumnya yang dilakukan oleh Sari dan Wardhana (2013) yang menyatakan bahwa Store Layout secara parsial berpengaruh signifikan terhadap kepuasan konsumen pada Roemah Kopi Bandung.

\section{Interior Display $\left(\mathbf{X}_{4}\right)$}

Interior Display merupakan dekorasi, pajangan, tanda yang digunakan untuk memberikan informasi kepada konsumen yang bertujuan untuk meningkatkan laba bagi toko. Adapun indikator-indikator 
yang digunakan untuk mengukur elemen Interior Display adalah gambar/poster menarik, gambar/tanda sesuai dengan tema, tanda petunjuk toilet, tanda petunjuk kasir, dan pajangan-pajangan dalam cafe. Penelitian yang dilakukan pada Cafe Refresho di Kota Palu, pada elemen Interior Display dimana tanda petunjuk kasir merupakan indikator yang dominan dipilih oleh responden. Selain itu pajangan-pajangan dalam cafe juga merupakan indikator yang dapat meningkatkan kepuasan konsumen pada Cafe Refresho di Kota Palu.

Berdasarkan hasil penelitian ini, indikator-indikator yang digunakan untuk mengukur Interior Display berpengaruh signifikan terhadap kepuasan konsumen Cafe Refresho. Hal ini menunjukkan bahwa Interior Display dapat mempengaruhi kepuasan konsumen pada Cafe Refresho di Kota Palu Hasil penelitian ini sejalan dengan penelitian sebelumnya yang dilakukan oleh Aryanto (2010) yang menyatakan bahwa Interior Display secara parsial berpengaruh signifikan terhadap kepuasan konsumen berbelanja pada Spesiez Distro di Kota Palu.

\section{KESIMPULAN DAN SARAN}

\section{Kesimpulan}

Berdasarkan hasil penelitian yang telah dijabarkan, maka diperoleh kesimpulan mengenai pengaruh store atmosphere terhadap kepuasan konsumen Cafe Refresho di Kota Palu.

1. Store Atmosphere, yang terdiri dari Exterior, General Interior, Store Layout, dan Interior Display secara simultan berpengaruh signifikan terhadap kepuasan konsumen pada Cafe Refresho di Kota Palu.

2. Exterior secara parsial berpengaruh tidak signifikan terhadap kepuasan konsumen pada Cafe Refresho di Kota Palu.

3. General Interior secara parsial berpengaruh signifikan terhadap kepuasan konsumen pada Cafe Refresho di Kota Palu.

4. Store Layout secara parsial berpengaruh signifikan terhadap kepuasan konsumen pada Cafe Refresho di Kota Palu.

5. Interior Display secara parsial berpengaruh signifikan terhadap kepuasan konsumen pada Cafe Refresho di Kota.

\section{Saran}

Berdasarkan kesimpulan yang telah diuraikan sebelumnya, maka saran-saran yang tepat menyangkut kegunaan penelitian ini dapat diuraikan sebagai berikut:

1. Kepada pemilik Cafe Refresho untuk lebih mengembangkan lagi store atmosphere, karena pada penelitian ini store atmosphere memiliki kontribusi yang cukup besar yaitu 68.4\% terhadap kepuasan konsumen di Cafe Refresho, khususnya bagian store layout (tata letak dalam toko), karena sesuai hasil penelitian di lapangan variabel store layout (tata letak dalam toko) paling dominan mempengaruhi kepuasan konsumen pada Cafe Refresho di Kota Palu. Sebaiknya pemilik Cafe Refresho menyediakan kursi dan meja yang banyak agar dapat menampung semua konsumen yang datang, merapikan fasilitas-fasilitas toko, dan memberi jalan yang luas sehingga konsumen mudah untuk berlalu lalang dalam cafe.

2. Kepada pemilik Cafe Refresho diharapkan juga memfokuskan unsur Interior Display (Pajangan) berkaitan dengan store atmosphere terutama dalam menghadapi persaiangan. Hal ini sesuai dengan hasil penelitian dilapangan, dimana faktor Interior display (Pajangan) merupakan faktor kedua yang paling dominan mempengaruhi kepuasan konsumen pada Cafe Refresho di Kota Palu. Sebaiknya pemilik Cafe Refresho membuat pajangan atau poster-poster, ataupun gambar-gambar didinding yang lebih menarik, mengingat gaya hidup masyarakat zaman sekarang yang senang untuk berfoto-foto dengan latar dinding atau gambar yang menarik.

3. Kepada pemilik Cafe Refresho sebaiknya juga memperhatikan unsur General Interior (bagian dalam cafe) karena sesuai hasil penelitian lapangan faktor General Interior (bagian dalam cafe) juga berpengaruh terhadap kepuasan konsumen. Sebaiknya pemilik Cafe Refresho lebih 
memperhatikan pencahayaan di cafe, musik yang dimainkan, aroma makanan, karyawan yang rapi dan ramah, menggunakan peralatan yang terlihat modern, dan kebersihan.

4. Kepada peneliti selanjutnya disarankan untuk memasukkan variabel lain seperti variabel kualitas layanan dan lain-lain, selain yang digunakan dalam penelitian ini sehingga lebih dapat mengukur sebab-sebab yang mempengaruhi kepuasan konsumen Cafe Refresho di Kota Palu, selain itu juga diharapkan untuk menggunakan ukuran sampel yang lebih besar dari jumlah sampel yang digunakan pada penelitian ini sehingga keakuratan hasil penelitian akan lebih terjamin.

\section{REFERENSI}

Adrian, I. (2015, May 13). Cara Melakukan Uji Normalitas Melalui Kolmogorov

Smirnov atau Grafik Q-Q Plot. Retrieved April 23, 2017, from

http://bimbingan-skripsi-malang.blogspot.com/2015/05/cara-melakukanujinormalitas-melalui.html

Aji, R. I. (2016). Pengaruh Store Atmposphere dan Lokasi Terhadap Proses Keputusan Pembelian Konsumen FJ Cafe Bandung (Survei Pada Konsumen FJ café Bandung). Universitas Pasundan, Bandung. Diambil dari (http://onesearch.id/Record/IOS3183.12522?widget=1\&repository_id=3183)

Albagdadi, Umi Kalsium Y (2017). Pengaruh Elemen Suasana Toko terhadap

Kepuasan Konsumen Berbelanja di Swalayan Inti Makmur Kota Palu. Universitas Tadulako. Palu.

Berman, B., \& Evans, J. R. (2010). Retail Management: A Strategic Approach (10 ed.). New Jersey: Pearson.

Duwi. (2011, November 27). Uji Heterokedasitas. Retrieved April 23, 2017, from http://duwiconsultant.blogspot.com/2011/11/uji-heteroskedastisitas.html

Ferdinand, A. (2014). Metode Penelitian Manajemen: Pedoman Penilitian Untuk Penulisan Skripsi, Thesis, dan Disertai Ilmu Manajemen (5 ed.). Semarang: Undip Press.

Gay, L. ., \& Diehl, P. . (1992). Research Methods for Business and Management. New York: MacMillan Publishing Company.

Hasan, A. (2009). Marketing (1 ed.). Yogyakarta: Media Pressindo.

Kotler, P., \& Keller, K. L. (2013). Marketing Management (14 ed.). England: Pearson.

Rahma, G. (2016, April 18). Uji Asumsi Klasik. Retrieved April 23, 2017, from http://ghinarahmatullah.blogspot.com/2016/04/uji-asumsi-klasik.html

Sugiyono. (2009). Metode Penelitian Bisnis (Pendekatan Kuantitatif, Kualitatif, dan R\&D). Bandung: Alfabeta.

Tendean, A., \& Widodo, A. (2015). Pengaruh Store Atmosphere Terhadap Kepuasan Konsumen (Studi pada Maja House Sugar \& Cream Bandung). Diambil dari (https://openlibrary.telkomuniversity.ac.id/pustaka/102031/pengaruh-store-atmosphereterhadap-kepuasan-konsumen-studi-pada-maja-house-sugar-cream-bandung-.html)

Utami, C. W. (2010). Manajemen Ritel: Strategi dan Implementasi Operasional Bisnis Ritel Modern di Indonesia (2 ed.). Salemba Empat.

Wanti, S. F. (2015). Pengaruh Experiantial Marketing dan Store Atmosphere Terhadap Kepuasan Pelanggan Chinggu Korean Fan Cafe Bandung (Thesis). Universitas Widyatama. Diambil dari (http://repository.widyatama.ac.id/xmlui/handle/123456789/6397)

Yamin, S., and Kurniawan, H. (2014). SPSS Complete (2nd ed.). Jakarta: Salemba. 